\title{
Rola dynamicznej posturografii komputerowej w diagnostyce wad zgryzu - przegląd piśmiennictwa
}

\author{
The role of computerized dynamic posturography in the diagnosis of malocclusion \\ - a literature review
}

\author{
${ }^{1}$ Pracownia Miniimplantów Ortodontycznych, Katedra i Klinika Ortopedii Szczękowej i Ortodoncji \\ Uniwersytet Medyczny im. Karola Marcinkowskiego w Poznaniu \\ ${ }^{2}$ Katedra i Klinika Ortopedii Szczękowej i Ortodoncji, Uniwersytet Medyczny im. Karola Marcinkowskiego w Poznaniu
}

DOI: http://dx.doi.org/10.20883/df.2016.11

\begin{abstract}
Streszczenie
Komputerowa posturografia dynamiczna jest zespołem różnych metod badawczych, pozwalających ocenić jakość kontroli postawy ciała. Jest badaniem rejestrującym i oceniającym reakcje posturalne, czyli odpowiedzi ruchowe całego ciała na bodźce zewnętrzne, u podstaw których leżą reakcje odruchowe, zależne od czasu utajenia reakcji powstających w mięśniach szkieletowych. U podstaw etiologii wad zębowo-zgryzowych w odniesieniu do przestrzennych płaszczyzn ciała: pośrodkowej, poziomej i pionowej, jako jeden z głównych czynników predysponujących leżą zaburzenia napięcia mięśni szkieletowych, którym mogą towarzyszyć wady postawy. Celem niniejszej publikacji jest zaprezentowanie roli dynamicznej posturografii komputerowej w ortodontycznej diagnostyce wad zgryzu, na podstawie piśmiennictwa.
\end{abstract}

Słowa kluczowe: diagnostyka ortodontyczna, posturografia, wady postawy, wady zgryzu.

\begin{abstract}
Computerized dynamic posturography is a set of different research methods to assess the quality of postural control. This involves recording and evaluating postural reactions; that is motor responses of the whole body to external stimuli based on stretch reflexes and atrio-core, time-dependent latency responses originating in the skeletal muscles. As regards the aetiology of dental-occlusal defects in relation to the spatial planes of the body, median, horizontal and vertical skeletal muscle disorders are indicated as one of the main predisposing factors which may be accompanied by postural defects. The aim of this publication is to present the role of computerized dynamic posturography in the diagnosis of orthodontic malocclusion, on the basis of the literature.
\end{abstract}

Keywords: orthodontic diagnosis, posturography, posture defects, malocclusion.

\begin{abstract}
Wstęp
Komputerowa posturografia dynamiczna (computerized dynamic posturography - CDP) jest zespołem różnych metod badawczych, pozwalających ocenić jakość kontroli postawy ciała. Jest badaniem rejestrującym i oceniającym reakcje posturalne, czyli odpowiedzi ruchowe całego ciała na bodźce zewnętrzne, u podstaw których leżą odruchy rozciągowe i przedsionkowo-rdzeniowe, zależne od czasu utajenia reakcji powstających w mięśniach szkieletowych. Wyróżnia się trzy rodzaje reakcji posturalnych [1]. Najszybciej pojawiają się odpowiedzi o latencji 50 ms, powstałe w wyniku działania odruchu z rozciągania mięśni kontrolujących ustawienie stawów kończyn i tułowia. Odruch inicjowany jest przez pobudzenie wrzecion mięśniowych - proprioreceptorów narządu ruchu. Powstały bodziec nerwowy przekazywany jest następnie do rdzenia kręgowego, gdzie po przełączeniu na kolejną synapsę powraca aksonem
\end{abstract}

odśrodkowym do włókien mięśniowych sąsiadujących z pobudzonym wrzecionem, powodując ich aktywację i usztywnienie stawu [2, 3]. Jako drugie pojawiają się w czasie od 90 do 120 ms reakcje korygujące postawę ciała. Jako trzecie, po około 240 ms ujawniają się odpowiedzi stabilizujące postawę. Dwie ostatnie reakcje mają charakter wielomięśniowy i znajdują się pod kontrolą odruchów przedsionkowo-rdzeniowych oraz odruchów wywołanych z pobudzenia proprioreceptorów kończyn dolnych i tułowia. Pojawiają się one prawie równocześnie w mięśniach kończyn dolnych, tułowia i szyi, stąd panuje opinia, że mechanizmy, które je inicjują, są koordynowane ośrodkowo.

$U$ podstaw etiologii wad zębowo-zgryzowych w odniesieniu do przestrzennych płaszczyzn ciała: pośrodkowej, poziomej i pionowej, jako jeden z głównych czynników predysponujących leżą zaburzenia napięcia mięśni szkieletowych, którym mogą towarzyszyć wady postawy. W wadach 
dotylnych stwierdza się nadczynność mięśni cofających żuchwę, w wadach doprzednich mięśni wysuwających dolny łuk zębowy. W badaniu klinicznym pacjentów z wadami pionowymi obserwuje się nadmierny tonus mięśni żwaczy lub ich hipotonię.

\section{Materiał i metody}

Założeniem niniejszej publikacji było przeanalizowanie doniesień na temat roli dynamicznej posturografii komputerowej w ortodontycznej diagnostyce wad zgryzu i odpowiedź na pytanie, czy obecnie występujące tak licznie wady postawy ciała mają wpływ na występowanie wad zgryzu. W tym celu przeanalizowano piśmiennictwo z zasobów bibliotecznych $z$ ostatnich lat. Kryterium wyszukiwania stanowiły hasła: diagnostyka ortodontyczna, posturografia, wady postawy, wady zgryzu. Ostatecznie wybrano do przeanalizowania 20 z 43 publikacji.

\section{Wyniki}

Posturografia jest zespołem rożnych metod badawczych pozwalających ocenić jakość kontroli postawy ciała [4]. Do opisu reakcji posturalnych stosuje się najczęściej model wahadła odwróconego z zamkniętym układem sterowania [5, 6]. Jak wskazują badania, środek ciężkości ciała człowieka w pozycji stojącej nie znajduje się w jednym punkcie. Wykonuje on cały czas chaotyczne ruchy w wielu płaszczyznach o amplitudzie kilku milimetrów, tzw. wychwiania ciała, które odpowiedzialne są za wolnozmienną składową przemieszczeń środka ciężkości ciała. Natomiast szybkozmienną składową tych ruchów są momenty siły bezładności powstające przy udziale mięśni szkieletowych, a warunkujące przywrócenie równowagi ciała [7, 8, 9]. Dlatego dokładna analiza ruchów środka ciężkości ciała umożliwia uzyskanie informacji o aktualnej stabilności osoby badanej, tzw. stabilności posturalnej [10]. Wychwiania ciała cechuje znaczna zmienność osobnicza. Nawet u tej samej osoby obserwuje się zmiany w zależności od kolejności badania [11]. Stąd do dnia dzisiejszego w badaniach posturograficznych nie wyodrębniono grup jednorodnych o określonych parametrach, które byłyby charakterystyczne dla określonych stanów fizjologicznych lub schorzeń. Podjęto wprawdzie próby stworzenia norm dla parametrów posturograficznych, ale niestety z miernym skutkiem [12]. Spowodowane jest to zmiennością osobniczą. Liczne badania wykazały, że nie ma ludzi o idealnej postawie ciała. Każdy niestety posiada jakąś wadę lub dysfunkcję. Ponadto Peterson i wsp. udowodnili, że dzieci młodsze niż 12-letnie nie potrafią w pełni wykorzystywać bodźców wzrokowych i przedsionkowych do kontroli postawy ciała [13]. Natomiast Steindl i wsp. wykazali brak tej integracji bodźców z narządu wzroku i przedsionka podczas utrzymywania wyprostnej postawy ciała aż do 15-16. roku życia [14]. Jest to interesujące dla ortodontów z perspektywy badań nad etiologią licznych wad zgryzu, obecnie występujących u dzieci. Jak wskazują wyniki wielu badań, cywilizacja zmienia środowisko, w którym żyjemy, a wraz z nim poszczególne etapy rozwoju człowieka. Z każdym pokoleniem stajemy się wyżsi i niestety bardziej otyli, a także prowadzimy siedzący tryb życia z małą ilością ruchu na świeżym powietrzu. Wzrasta przez to zagrożenie chorobami cywilizacyjnymi, takimi jak zaburzenia gospodarki lipidowej, cukrzyca, nadciśnienie tętnicze krwi czy wady postawy [15]. Otaczające nas środowisko wpływa na zwiększenie chorób o podłożu molekularnym, które mogą przyczyniać się do dynamicznych zmian w wieku kostnym [16]. Trend sekularny sprawia, że siatki centylowe trzeba uaktualniać co kilkadziesiąt lat. Należałoby zastanowić się, czy cywilizacja ma także wpływ na proces powstawania i kształtowania uzębienia człowieka. U dzieci w wieku 6-7 lat procesy rozwoju są harmonijne. Źródeł negatywnych zmian można doszukać się w nowych dla dziecka warunkach funkcjonowania w domu i szkole, jakimi są: brak czasu rodziców i zajmowanie dzieci tabletami, obciążanie postawy poprzez niewłaściwe siedzenie, noszenie ciężkich plecaków, zmęczenie, trudne przeżycia wywołujące opuszczenie głowy i garbienie się. Czynniki te zdają się mieć istotny wpływ na powstawanie wad zgryzu [17]. Utrzymanie stabilnej, pionowej postawy ciała wymaga analizy bodźców z trzech układów: wzrokowego, ruchowego (bodźce proprioceptywne) i przedsionkowego. Informacje o przemieszczeniu środka ciężkości ciała są analizowane w ośrodkowym układzie nerwowym, gdzie dochodzi do aktywowania ośrodków układu ruchu w taki sposób, aby ograniczyć kołysanie ciała [3]. Zwraca się uwagę, aby środek ciężkości nie przemieścił się poza anatomiczne granice podparcia, czyli poza pole przylegania stóp do podłoża. U człowieka środek ten zlokalizowany jest na poziomie lędźwi. Stabilność postawy utrzymywana jest dzięki podświadomym odruchom prostowania (monosynaptyczny odruch prosty na rozciąganie) oraz odruchom równowagi (złożone automatyzmy ruchowe) powstającym na wyższych piętrach układu nerwowego pomiędzy korą, móżdżkiem, jądrami podkorowymi i pniem mózgu [18]. Dynamiczna posturografia komputerowa (CDP) umożliwia ilościową ocenę czynności układu równowagi podczas wykonywania prób statycznych i dynamicznych [19]. Umożliwia także monitorowanie rozwoju zmian statyczno-dynamicznych u sportowców w trakcie wykonywanych treningów i ćwiczeń mięśniowych po upływie dwóch lat [20]. Należy zwrócić uwagę, że w profilaktyce zaburzeń w obrębie narządu żucia, jakimi są wady zgryzu, zaleca się pacjentom wykonywanie ćwiczeń mięśniowych ingerujących w poprawę całej postawy, np. ćwiczenia Rogersa [21]. Wielu badaczy wykazało szcze- 
gólną przydatność tych ćwiczeń u pacjentów ze schorzeniami neurologicznymi oraz układu kostno-stawowego - głównie w zakresie diagnostyki oraz monitorowania procesów przebiegu leczenia $[22,23]$.

\section{Podsumowanie}

Po przeanalizowaniu literatury nasuwa się pytanie, czy metoda dynamicznej posturografii komputerowej (CDP) może stać się badaniem przesiewowym w wykrywaniu skojarzonej patologii w obrębie układu kostno-mięśniowego, nerwowego, ze szczególnym uwzględnieniem zaburzeń narządu żucia. Wydaje się, że nowa technika posturografii dynamicznej, imitująca zwykłą, codzienną aktywność człowieka, może służyć ocenie funkcji całego układu równowagi, jak i ocenie ryzyka wystąpienia wad zgryzu. Warto byłoby odpowiedzieć na pytanie, czy rejestracja odruchów wyprostnych ciała z zastosowaniem posturografii dynamicznej mogłaby stanowić podstawę testów umożliwiających ilościową oraz jakościową ocenę uszkodzeń w odniesieniu do wad zgryzu. Praktyczne zastosowanie CDP w badaniach stomatologicznych w odniesieniu do ortodoncji może stanowić interesujący temat badań klinicznych nad ciągle stawianym pytaniem o dokładną korelację pomiędzy wadą postawy a wadą zgryzu. Analiza ta wymaga jednak dalszych precyzyjnych badań.

\section{Oświadczenia}

Oświadczenie dotyczące konfliktu interesów

Autorzy deklarują brak konfliktu interesów w autorstwie oraz publikacji pracy.

\section{Źródła finansowania}

Autorzy deklarują brak źródeł finansowania.

\section{Piśmiennictwo}

[1] Allum JHJ, Shepard NT. An overview of the clinical use of dynamic posturography in the differential diagnosis of balance disorders. J Vest Res. 1999;9:223-252.

[2] Houk JC. Regulation of stiffness by skeletomotor reflexes. Ann Rev Physiol. 1979;41:99-114.

[3] Held-Ziółkowska M. Równowaga statyczna i dynamiczna. Część 1. Mag Otorynolaryngol. 2006;18:39-46.

[4] Bosek M i wsp. Degradation of postural control system as a consequence of Parkinson's disease and ageing. Neurosci Lett. 2005;16(376):215-220.

[5] Ishida A, Miyazaki S. Maximum likelihood identification of a posture control system. IEEE TransBiomed Eng. 1987;34(1):1-5

[6] Johansson R, Magnusson M. Human postural dynamics. Crit Rev Biomech Eng. 1991;18:413-437.

[7] Kuczyński M. Sterowanie lepko-sprężyste w układzie równowagi człowieka. Czlowiek i Ruch. 2001; 2(4):33-38.

[8] Olton J, Czerwosz L. Posturograf firmy Pro-Med. Acta Bio-Opt Inform Med. 2006;3(12):143-144.

[9] Szczepek E, Czerwosz L, Dąbrowski P, Dudziński K, Jurkiewicz J, Czernicki Z. Badanie posturograficzne i kompu- terowa analiza chodu w systemie Komputer Dyno Grapy jako nieinwazyjne metody zaawansowania wodogłowia normotensyjnego. Neurol Neurochir Pol. 2008;42(2):139_ 152.

[10] Błaszyk JW. Kontrola stabilności postawy. Kosmos. 1993;49(2):473-486.

[11] Kuczyński M. Regulacja pozycji pionowej człowieka: od metod oceny do mechanizmów. Człowiek i Ruch. 2000;2(2):34-41.

[12] Bizzo G, Guillet N, Patat A, Gagey PM. Specifications for building a vertical force platform desidned for clinical stabilometry. Med Biol Eng Comput. 1985;23:474-476.

[13] Peterson M, Christiu E, Rosengren K. Children achieve adult-like sensory integration during stance at 12 years old. Gait \& Posture. 2006;23:455-463.

[14] Steindl R, Kunz K, Schrott-Fischer A, Scholtz A. Effect of age and sex on maturation of sensory systems and balance control. Development Medicine \& Child Neurology. 2006;48:477-482.

[15] Kopczyński P, Kęsy L, Flieger R, Thielemann A. Przedimplantacyjna ocena stanu zdrowia pacjenta na podstawie badań laboratoryjnych. Twój Prz Stom. 2013;12.

[16] Flieger R, Kopczyński P, Matthews-Brzozowska T. Analysis of skeletal maturity of children with cleft palate in terms of healthy children by the CVM method. Adv Clin Exp Med. 2015;24(1):99-102.

[17] Walicka- Cupryś K, Skalska-Izdebska R, Drzał-Grabiec J, Sołek A. Związek pomiędzy postawą ciała i stabilnością posturalną u dzieci w wieku wczesnoszkolnym. Postępy Rehabilitacji. 2013;4:47-54.

[18] Sobera M. Charakterystyka procesu utrzymywania równowagi ciała u dzieci w wieku 2-7 lat. Wydawnictwo AWF, Wrocław 2010; 12-13.

[19] Olejarz P, Olchowik G. Rola dynamicznej posturografii komputerowej w diagnostyce zaburzeń równowagi. Otorynolaryngologia. 2011;10(3):103-110.

[20] Poliszczuk T, Broda D, Poliszczuk D. Changes in somatic parameters and dynamic balance in female rhythmic gymnasts over a space of two years. Pol J Sport Tourism. 2012;19:240-252.

[21] Ćwirzeń W, Szepietowska M, Miazek-Wagner M. Mioterapia w leczeniu wad ortodontycznych - zasady stosowania. Nowa Stomatologia. 2010;3:123-129.

[22] Pothula VB, Chew F, Lesser THJ, Dharma AK. Falls and vestibular impairment. Clin Otolaryngol. 2004;29:179.

[23] Mraz M, Curzytek M, Mraz M. i wsp. Stabilność posturalna osób z uszkodzeniem układu nerwowego. Acta Bio-optica et Informatica Medica. 2008;14.

Zaakceptowano do edycji: 2016-04-28 Zaakceptowano do publikacji: 2016-05-06
Adres do korespondencji:
Łucja Sobkowska
Pracownia Miniimplantów Ortodontycznych
Katedra i Klinika Ortopedii Szczękowej i Ortodoncji
Uniwersytet Medyczny im. Karola Marcinkowskiego
w Poznaniu
ul. Bukowska 70, 60-812 Poznań
tel.: 695772700
e-mail: lucja.sobkowska@gmail.com 